\title{
МИРОВОЙ УГЛЕРОДНЫЙ РЫНОК В СТАДИИ ЗАРОЖДЕНИЯ
}

\author{
Н.А. Иванов ${ }^{1}$
}

В ноябре 2021 г. в Глазго состоится 26 Конференция сторон рамочной конвенции ООН об изменении климата (СОР26). Помимо общих вопросов достижения государствами углеродной нейтральности и борьбы с эмиссиями парниковых газов на повестке неизбежно окажется вопрос становления и развития мирового рынка углеродных эмиссий. Но и помимо официального международного утверждения углеродный рынок развивается на разных уровнях - от государственного до корпоративного, от обязательного до добровольного. Движение по установлению цены углеродных эмиссий уже становится массовым и скоро может стать глобальным - независимо от межгосударственных договоренностей на уровне $00 \mathrm{H}$.

Последние 10-15 лет страны разрабатывают и внедряют рыночные механизмы, способствующие борьбе с изменением климата. По оценкам Climate Policy Initiative ${ }^{2}$, для удержания роста глобальной температуры в пределах 1,5 градусов Цельсия требуются инвестиции в объеме \$1,6-3,8 трлн. По данным на 2020 год на эти цели инвестировано всего \$463 млрд.

Установление цены на выбросы углерода считается наиболее эффективным инструментом климатической политики. Это фундаментально меняет экономические стимулы, в результате чего эмитировать парниковые газы становится всё более дорого. По мере роста цены на углеродные эмиссии эмитенты (энергетические компании, крупные производственные потребители энергоресурсов и т.п.) получают ясный сигнал для принятия инвестиционных решений, направленных на снижение эмиссий.

Ценообразование на углерод может принимать две основные формы углеродный налог, устанавливаемый правительствами, и система торговли выбросами (emissions trading system, ETS) или углеродный рынок. Углеродные налоги работают так же как и другие инструменты фискальной политики, устанавливая цену на выбросы парниковых газов. ETS, напротив, создает рынок торговли разрешениями на выбросы, выпущенными правительствами, как правило, в виде единиц, соответствующих одной тонне эквивалента диоксида углерода (tCO2e).

Рынок торговли этим новым классом активов быстро развивается. К 2020 году 57 стран ввели системы углеродного ценообразования, что на 34\% больше, чем в 2017 г. К марту 2021 года 124 страны приняли или готовятся принять цели по достижению климатической нейтральности. Эти страны представляют 61\% совокупных эмиссий

1 Иванов Николай Александрович, доцент кафедры международного нефтегазового бизнеса РГУ нефти и газа имени И.М. Губкина

${ }^{2}$ https://www.climatepolicyinitiative.org/the-topics/climate-finance-landscapes/ 
парниковых газов, 56\% мирового населения и 68\% глобального ВВП. И хотя не во всех этих странах действуют системы углеродного ценообразования, дело идет именно к этому.

Ожидается, что распространение этой практики не просто продолжится, но будет происходить конвергенция региональных углеродных рынков, а после активации Статьи 6 Парижского соглашения глобализация углеродного рынка станет реальностью.

10 марта 2021 г. Европарламент поддержал введение пограничного углеродного налога на импортируемые товары с высоким содержанием углерода с 2023 года, а 14 июля Европейская комиссия представила пакет законодательных инициатив, призванных обеспечить достижение цели, установленной в рамках т.н. Европейского зеленого проекта (European Green Deal), а именно сократить выбросы в атмосферу парниковых газов (ПГ) к 2030 году на 55\% от уровня 1990 г. Пакет так и называется - «Fit for 55», а содержащиеся в нем 15 законопроектов затрагивают все аспекты деятельности и сектора экономики ЕС, которые связаны с выбросами ПГ. В этот пакет входит также документ о механизме трансграничного углеродного регулирования (Carbon border adjustment mechanism, CBAM), который устанавливает порядок декларирования и оплаты импортерами углеродного следа продукции, ввозимой на территорию ЕС из стран, где выбросы ПГ регулируются недостаточно жестко или не регулируются вообще. По оценке KPMG, в зависимости от сценария введение механизма СВАМ может стоить российским экспортерам от 6 до 50 млрд долларов за весь период до 2030 г.

Но проблема может оказаться сложнее: европейский пограничный налог окажется одним из составных элементом мирового углеродного регулирования. Цена на углеродные эмиссии станет не европейской, а глобальной.

Хотя цель декарбонизации экономики стран ясна, еще трудно определить оптимальные политические рамки, бизнес-модели и технологии, необходимые для ее достижения. Поэтому важно не только учитывать риски, связанные с возможным образованием глобального углеродного рынка, но и распознавать инвестиционные перспективы, находить возможности для встраивания в этот новый рынок.

\section{Что такое цена углеродных эмиссий}

Цена углерода - это инструмент, определяющий стоимость эмиссий парниковых газов, которую платит общество за ущерб для окружающей среды и здоровья населения, вызываемый последствиями изменения климата. Цена углеродных эмиссий выражается в стоимости эмиссий эквивалента весовой единицы диоксида углерода (CO2).

Установление цены на углерод позволяет переложить ответственность за эмиссии парниковых газов на тех, кто производит эти эмиссии. Вместо того чтобы определять, кто должен сокращать эмиссии, как именно и насколько, цена на эмиссии углерода создает экономические стимулы, подает сигнал компаниям, что они могут 
выбирать - модернизировать производства и сокращать выбросы, или продолжать работу по-старому и платить за выбросы. В результате достижение климатических целей становится наиболее реальным и наименее затратным для общества. Если адекватная цена на углеродные эмиссии установится в мировом масштабе, это ускорит переход экономик разных стран к чистому развитию. Будут мобилизованы финансовые ресурсы для инвестирования технологических прорывов в низкоуглеродной энергетике.

Как правительства, так и бизнес приходят к общему пониманию важности ценообразования на эмиссии углерода при переходе к декарбонизированной экономике. Для правительств ценообразование на углерод является одним из инструментов климатической политики, необходимой для сокращения выбросов. В большинстве случаев оно также является источником дохода, что особенно важно в условиях бюджетных ограничений. Предприятия используют внутреннее углеродное ценообразование для оценки влияния обязательных цен на углерод на их деятельность и в качестве инструмента для выявления потенциальных климатических рисков и возможностей получения дохода. Наконец, инвесторы используют углеродное ценообразование для анализа потенциального влияния политики в области изменения климата на их инвестиционные портфели, что позволяет им пересмотреть инвестиционные стратегии и перераспределить капитал в пользу низкоуглеродных или устойчивых к изменению климата видов деятельности.

Ценообразование на углерод может принимать различные формы и виды. Под углеродным ценообразованием понимаются инициативы, устанавливающие явную цену на выбросы ПГ, т.е. цену, выраженную в виде стоимости за тонну эквивалента углекислого газа (tCO2e). Если рассматривать различные подходы к ценообразованию на углерод, то система торговли выбросами (ETS), с одной стороны, обеспечивает определенность в отношении воздействия на окружающую среду, но цена остается гибкой. Налог на углерод, с другой стороны, гарантирует цену на углерод в экономической системе, но при этом неопределенным остается экологическое воздействие.

Существуют и другие виды ценового регулирования углеродного следа - это, например, климатическое финансирование, ориентированное на результат (resultsbased climate finance, RBCF) и устанавливаемые самими компаниями и организациями внутренние цены на углерод. Успешная декарбонизация экономики возможна только при широком распространении практики сокращения эмиссий и снижении стоимости перехода к чистой энергетике. Для ускорения перехода потребуется полный спектр подходов к ценообразованию на углерод, а также меры политической поддержки на национальном и межгосударственном уровне.

\section{Основные типы углеродного ценообразования}


Система торговли выбросами (emissions trading system, ETS) - это система, в которой эмитенты могут торговать единицами выбросов для достижения своих целевых показателей. Чтобы выполнить свои целевые показатели по эмиссиям с наименьшими затратами, компании могут либо реализовать внутренние меры по снижению выбросов, либо приобрести единицы выбросов на углеродном рынке в зависимости от относительной стоимости этих вариантов. Создавая спрос и предложение на единицы выбросов, ETS устанавливает рыночную цену на эмиссии ПГ. Два основных типа ETS - это система квот и торговли и система базовых показателей и кредитов:

- При системе квотирования и торговли применяется предельный или абсолютный лимит на выбросы в рамках ETS, а разрешения на выбросы распределяются бесплатно или через аукционы.

- В базисно-кредитной системе для отдельных регулируемых субъектов определяются базовые уровни выбросов, а кредиты выдаются компаниям, сократившим свои выбросы ниже этого уровня. Эти кредиты могут быть проданы другим организациям, превышающим базовые уровни выбросов.

Углеродный налог напрямую устанавливает цену на углерод, определяя явную налоговую ставку на выбросы ПГ или, что более распространено, на содержание углерода в ископаемом топливе, т.е. цену за тонну эквивалента углекислого газа (CO2e). Он отличается от ETS тем, что результат сокращения выбросов при углеродном налоге заранее не определен, но определена цена на углерод.

Механизм компенсации (офсета) определяет единицы сокращения выбросов ПГ в результате деятельности, осуществляемой в рамках проектов или программ, которые могут быть проданы как внутри страны, так и в других странах. Программы офсета выдают углеродные кредиты в соответствии с протоколом учета и имеют свой собственный реестр. Эти кредиты могут быть использованы для выполнения требований международного соглашения, внутренней политики или корпоративных гражданских целей, связанных со снижением выбросов ПГ.

RBCF - это подход к финансированию, при котором выплаты производятся после достижения и проверки заранее определенных результатов или итогов, связанных с управлением изменением климата, таких как сокращение выбросов. Многие программы RBCF направлены на приобретение подтвержденных сокращений выбросов парниковых газов, одновременно имея целью снижение уровня бедности, улучшение доступа к чистой энергии и обеспечения здоровья населения.

Внутреннее углеродное ценообразование - это инструмент, который организация использует внутри себя, чтобы направлять процесс принятия решений в отношении воздействия изменения климата, рисков и возможностей.

Для правительств выбор типа углеродного ценообразования зависит от национальных условий и политических реалий. В контексте инициатив по обязательному ценообразованию на углерод наиболее распространенными типами являются ETS и налоги на углерод. По состоянию на 2017 год 42 страны и 25 
субнациональных юрисдикций (города, штаты и регионы) уже имели инициативы по установлению цен на углерод, и еще больше стран планировали ввести цены на углерод в будущем.

Выбор наиболее подходящего типа инициативы зависит от конкретных обстоятельств и контекста конкретной юрисдикции, а политические цели инструмента должны быть согласованы с более широкими национальными экономическими приоритетами и институциональными возможностями. ETS и углеродные налоги все чаще используются в качестве взаимодополняющих инструментов, причем особенности обоих типов часто сочетаются, образуя гибридные подходы к ценообразованию на углерод. Некоторые инициативы также позволяют использовать кредиты от механизмов компенсаций в качестве гибкого инструмента для соблюдения требований.

Многие компании используют цену на углерод, с которой они сталкиваются в рамках обязательных инициатив, в качестве основы для своей внутренней цены на углерод. Некоторые компании принимают ряд внутренних цен на углерод, чтобы учесть различные цены в разных юрисдикциях и/или учесть будущее повышение обязательных цен на углерод.

Неявное ценообразование на выбросы ПГ может также осуществляться с помощью других политических инструментов, таких как отмена субсидий на ископаемое топливо, налогообложение энергии, поддержка возобновляемых источников энергии и торговля сертификатами энергоэффективности.

\section{Международная система углеродного ценообразования}

Международные инициативы по ценообразованию на углеродные эмиссии потенциально могут охватить весь мир. К ним относятся:

Инициативы в рамках Рамочной конвенции ООН по изменению климата (РКИК OOH, UNFCCC):

- Международная торговля выбросами (IET);

- Проекты совместного осуществления (ПСО, JI) и Механизм чистого развития (МЧР, CDM);

- Новые подходы в рамках статьи 6 Парижского соглашения.

Инициативы за пределами РКИК ООН:

- Добровольный углеродный рынок;

- Климатическое финансирование, ориентированное на результат (RBCF);

- Глобальные секторальные инициативы.

Международное ценообразование на углерод началось с введением механизмов гибкости в рамках Киотского протокола. Принятый на третьей Конференции сторон (КС) РКИК ООН в Киото, Япония, в декабре 1997 года, Киотский протокол обязал подписавшие его промышленно развитые страны (так называемые 
страны Приложения I) коллективно сократить выбросы парниковых газов в среднем на 5,2\% ниже уровня 1990 года в течение 2008-2012 годов. Страны Приложения I могли выполнить свои обязательства за счет внутренних действий или использования трех гибких механизмов IET, JI и CDM. Поправка, принятая в Дохе, Катар, в декабре 2012 года, заложила основу для продолжения работы трех Киотских механизмов на 2013-2020 годы, чтобы они могли способствовать созданию трансграничных углеродных рынков.

В перспективе ценообразование на углерод может сыграть ключевую роль в реализации амбиций Парижского соглашения и выполнении обязательств в соответствии с определяемыми на национальном уровне вкладами ${ }^{3}$ (NDCs). Статья 6 Парижского соглашения обеспечивает основу для содействия международному признанию совместных подходов к ценообразованию на углерод и определяет новые концепции, которые могут проложить путь для осуществления такого сотрудничества. Параграф 136 первого Решения СОР 21 (Принятие Парижского соглашения) ${ }^{4}$ признает важную роль создания стимулов для деятельности по сокращению выбросов, включая такие инструменты, как внутренняя политика и углеродное ценообразование. Многие планы, представленные в РКИК ООН, признают важную роль ценообразования на углерод, при этом около 100 стран планируют или рассматривают механизмы ценообразования на углерод в своих предполагаемых NDCs.

Международная торговля выбросами (International Emissions Trading, IET) - это международная ETS, созданная с намерением позволить странам Приложения I добиться сокращения выбросов с наименьшими затратами. Однако отдельные страны принимали политические решения, связанные с другими приоритетами и национальным контекстом, и не всегда оптимизировали свои усилия по сокращению выбросов только на основе цены на углерод. Такая неоднородность национальной политики привела к тому, что IET не достигла результата с наименьшими затратами, как предполагалось изначально. IET также мешало отсутствие ясности в отношении экологических результатов, что повлияло на ее привлекательность для суверенных покупателей.

Проекты совместного осуществления (ПСО) и механизм чистого развития (МЧР) являются механизмами компенсации в рамках Киотского протокола, в соответствии с которыми организации из Сторон, включенных в Приложение I, могут участвовать в низкоуглеродных проектах и получать взамен кредиты.

- МЧР - это рыночный механизм, который привлек наибольшее количество стран - как развитых, так и развивающихся - к усилиям по сокращению выбросов ПГ. Он вырос до таких масштабов, что позволил добиться значительного сокращения выбросов и обеспечить финансовые потоки в развивающиеся страны. Развивающиеся страны

\footnotetext{
${ }^{3}$ https://unfccc.int/ru/peregovornyy-process-i-vstrechi/parizhskoe-soglashenie/nationally-determinedcontributions-ndcs/opredelyaemye-na-nacionalnom-urovne-vklady

${ }^{4}$ https://unfccc.int/resource/docs/2015/cop21/rus/10r.pdf
} 
могут добровольно участвовать в мероприятиях по сокращению выбросов через МЧР. Сокращения выбросов затем передаются странам Приложения I для достижения их целевых показателей. К концу 2014 года МЧР поддержал инвестиции на сумму около \$90 млрд в проекты по сокращению выбросов ПГ в развивающихся странах. МЧР подтвердил, что офсетные механизмы способны эффективно мобилизовать капитал для экономически эффективных низкоуглеродных инвестиций.

- Механизм ПСО оказался менее успешным, чем МЧР, с точки зрения достижений в области сокращения выбросов, поскольку он сталкивается с двойной проблемой - недостатком амбиций стран и неопределенностью в отношении будущей нормативной инфраструктуры для выдачи кредитов. Большинство кредитов было выдано без контроля со стороны Комитета по надзору за совместным осуществлением, что не способствовало доверию к этому механизму.

К 2012 году спрос на киотские кредиты - сертифицированные сокращения выбросов (Certified Emission Reductions, CERs) от МЧР и единицы сокращения выбросов (Emission Reduction Units, ERUs) от ПСО - начал насыщаться. Стало ясно, что уже выпущенных киотских кредитов достаточно для удовлетворения большей части спроса, в том числе со стороны ЕС, который исторически был самым большим источником спроса. Поскольку других существенных источников спроса на киотские кредиты не существовало, это привело к устойчиво низким ценам на CERs и ERUs.

7 октября 2016 года государства-члены Международной организации гражданской авиации (ICAO) приняли первую глобальную отраслевую инициативу по установлению цен на углерод - Схему компенсации и сокращения выбросов углерода для международной авиации (CORSIA). Это глобальная инициатива по компенсации выбросов углерода, которая направлена на стабилизацию чистых выбросов от международной авиации на уровне 2020 года; любые дополнительные выбросы сверх уровня 2020 года должны быть компенсированы.

По предварительным оценкам, CORSIA может создать спрос на углеродные активы в размере около 2,5 Гт СО2е в период с 2021 по 2035 год, что сопоставимо с совокупным объемом выданных киотских кредитов. Спрос будет определяться правилами в отношении типа кредитов, которые авиакомпании смогут приобретать для соблюдения CORSIA.

Статья 6 Парижского соглашения признает, что Стороны могут добровольно сотрудничать в реализации своих NDCs, чтобы обеспечить более высокую амбициозность действий по предотвращению изменения климата и адаптации:

- Статьи 6.2-6.3 Парижского соглашения охватывают подходы к сотрудничеству, в рамках которых Стороны могут выбрать для выполнения своих NDCs использование переданных на международном уровне результатов предотвращения изменения климата (internationally transferred mitigation outcomes, ITMOs). ITMOs направлены на обеспечение основы для содействия международному признанию 
трансграничного применения субнациональных, национальных, региональных и международных инициатив по установлению цен на углерод.

- Статья 6.4 устанавливает механизм, позволяющий странам вносить вклад в смягчение последствий выбросов ПГ и устойчивое развитие. Этот механизм находится в ведении Конференции сторон РКИК ООН и открыт для всех стран, а сокращения выбросов могут быть использованы для выполнения NDC как принимающей страны, так и другой страны. Механизм предназначен для стимулирования деятельности по предотвращению изменения климата как государственных, так и частных организаций.

Точный характер ITMOs и архитектура механизма, предусмотренного статьей 6.4, все еще обсуждаются. Введение в действие новых механизмов в рамках Статьи 6 является одной из проблем, которую необходимо решить, чтобы позволить ценообразованию на углерод реализовать свой потенциал для экономически эффективной декарбонизации и адаптации.

Руководящие принципы Парижского соглашения, включая условия введения в действие совместных подходов к сокращению выбросов в соответствии со Статьей 6, должны были быть разработаны и приняты к декабрю 2018 года, но этого не произошло до сих пор. Есть вероятность, что переговоры завершатся к осени 2021 г. и Статья 6 будет принята на конференции сторон РКИК (СОР-26) в ноябре в Глазго.

\section{Региональные, национальные и местные системы ценообразования на углерод}

Парижское соглашение было подписано в 2015 г. странами, в совокупности представляющими около 90\% глобальных эмиссий парниковых газов. По предварительным оценкам, к настоящему времени системы углеродного ценообразования охватывают около 20\% глобальных эмиссий (11 млрд т СО2е), по сравнению с 7 млрд т СО2е в 2013 году.

Уже к 201742 страны и 25 региональные юрисдикции (города, штаты и регионы) установили ценообразование на углерод через ETS или углеродные налоги. Действовали 24 схемы ETS и 23 варианта углеродных налогов, главным образом на национальном уровне. За предыдущее десятилетие число юрисдикций с углеродным ценообразованием удвоилось.

К 2020 году стран, которые ввели системы углеродного ценообразования, было 57, что на $34 \%$ больше, чем в 2017 г.

К марту 2021 года уже 124 страны приняли или готовятся принять цели по достижению климатической нейтральности. Эти страны представляют 61\% совокупных эмиссий парниковых газов, 56\% мирового населения и 68\% глобального 
ВВП. И хотя не во всех этих странах действуют системы углеродного ценообразования, дело идет именно к этому.

Рисунок 1. Национальные, региональные и местные инициативы по созданию углеродного рынка, включая ETS и углеродные налоги

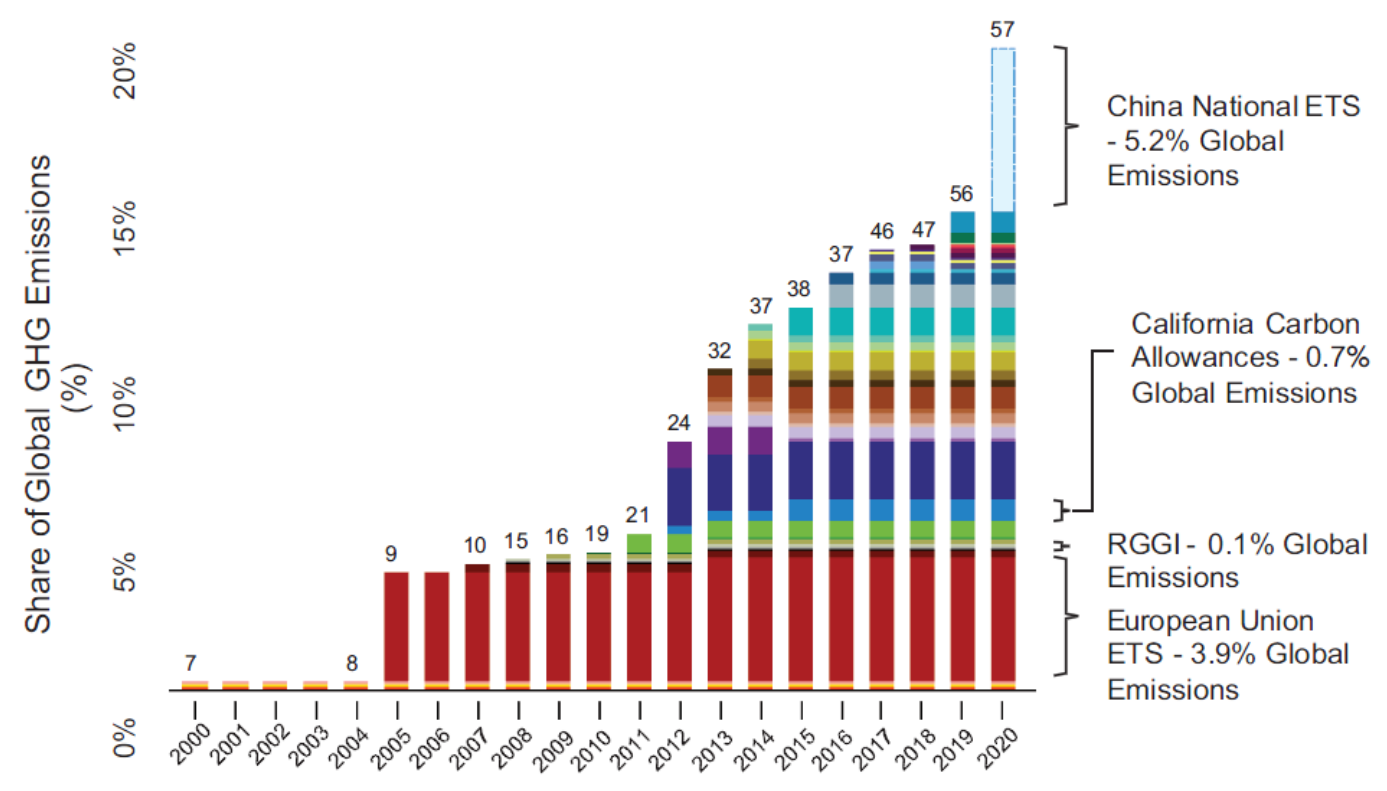

Источник: IHS Markit Global Carbon Index

\section{Крупнейшие углеродные рынки}

Три крупнейших и наиболее ликвидных углеродных рынка находятся в Европе, Калифорнии и на северо-востоке США. Совокупная рыночная стоимость этих рынков составляет \$52 млрд и 2,7 млрд т CO2е (март 2020 года) и продолжает расти как по объему кредитов, так и по общей рыночной стоимости.

По мере ускорения внедрения ценообразования на углерод, крупные экономики, вероятно, начнут внедрять ETS, создавая более ликвидные и инвестиционно привлекательные рынки. Ожидается, что эти системы будут иметь схожие движущие силы, которые ограничат предложение и со временем приведут к росту цен. Самые крупные из новых систем ценообразования на углерод находятся в Азиатско-Тихоокеанском регионе.

Китай, крупнейший в мире эмитент парниковых газов, объявил о запуске национальной системы торговли квотами на выбросы в 2020 году. Ожидается, что она охватит 3 300 млн т СО2е, что составит около 30\% национальных выбросов, что сделает ее крупнейшим углеродным рынком в мире - почти в два раза больше, чем EU ETS.

Текущая итерация Корейской системы торговли выбросами (KETS) началась в 2018 году, и средние цены составили \$18. Ожидается, что она будет охватывать 68\% всех национальных выбросов (около 85 млн т CO2е) и обеспечивать ежегодное сокращение общего лимита выбросов. ETS Новой Зеландии охватывает примерно 
половину национальных выбросов (около 40 млн т CO2е), и с 2017 года средняя цена составляет \$15/т CO2е.

Рисунок 2. Страны с различными системами ценообразования на углеродные эмиссии

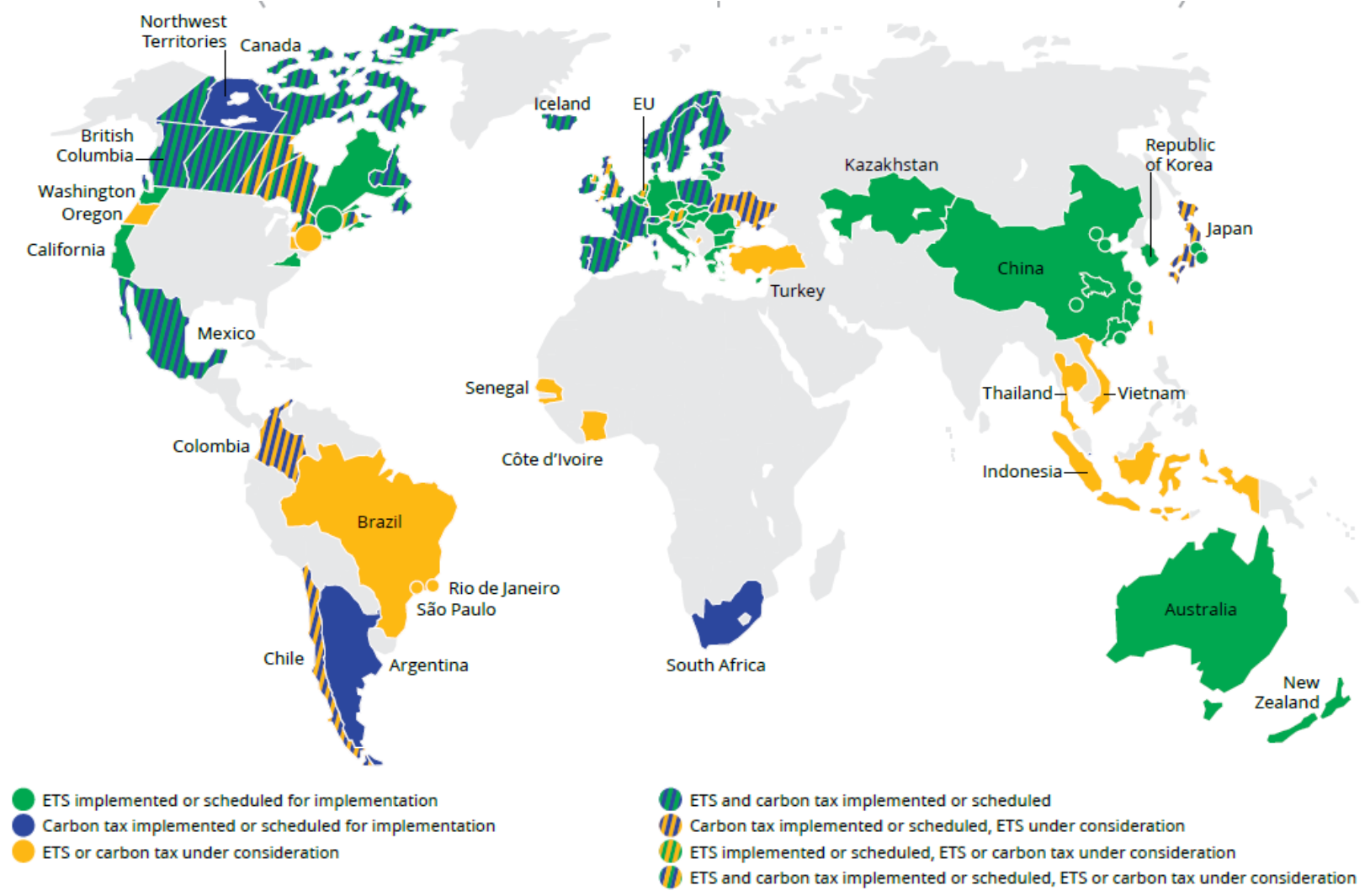

Источник: Всемирный банк

\section{Европейский Союз}

Система торговли выбросами Европейского союза (EU ETS) является старейшим, крупнейшим и наиболее ликвидным углеродным рынком в мире. Запущенная в 2005 году, EU ETS состоит из 32 государств-членов EC и охватывает 40\% выбросов парниковых газов в регионе. Более 12000 предприятий обязаны участвовать в ETS в энергетическом, промышленном, сельскохозяйственном и авиационном секторах. Цена за тонну углерода колебалась в течение последнего десятилетия, со значительным ростом с 2017 года. Общий объем выбросов в ЕС снизился на 350 млн т CO2е с начала действия программы.

EU ETS имеет несколько механизмов, предназначенных для контроля ценовой волатильности, которая возрастает по мере сокращения предложения углеродных квот. В период 2013-2020 годов 57\% квот продаются на аукционах по рыночной цене субъектам соблюдения, определяемой динамикой спроса/предложения, а остальные квоты распределяются бесплатно между секторами. Начиная с 2020 года, количество бесплатных квот будет сокращаться, постепенно переходя от исторически 
сложившегося избыточного предложения квот к вероятному дефициту на рынке, увеличивая спрос и объем сделок.

После периода чрезвычайно низких цен ЕС ввел резерв стабильности рынка (MSR), чтобы помочь избежать экстремальной волатильности рынка. MSR удерживает квоты вне аукциона, когда на рынке имеются избыточные объемы, и вновь вводит их в оборот при низком обращении. Не существует заранее установленных ценовых границ, однако этот механизм создает стабильность на рынке и повышает устойчивость к будущим скачкам спроса/предложения.

Продолжающийся экономический рост Европейского союза в сочетании с более строгими целями по сокращению выбросов приведет к нехватке квот на рынке, теоретически повышая цену и делая выбросы углерода более дорогими.

C 2018 года EU ETS собрала 35,9 млрд евро, которые поступают в распоряжение государств - членов ЕС; по крайней мере, половина из них должна быть использована на цели, связанные с климатом и энергетикой.

EU ETS вляется наиболее ликвидным фьючерсным рынком углеродных квот. C конца 2018 года по конец 2019 года общий объем торгов на этом рынке составил более $\$ 149$ млрд и в последние годы рос экспоненциально.

\section{Калифорния}

Калифорния является 5-й по величине экономикой. Основа климатических действий и системы ценообразования на углерод была заложена в 2006 г. Законом о решениях проблемы глобального потепления (Assembly Bill 32, AB32). Программа штата по ограничению и торговле углеродными эмиссиями Cap-and-Trade (CA C\&T) началась в 2013 году и охватывает около 80\% выбросов штата. Приблизительно 400 предприятий охвачены программой в таких секторах, как производство электроэнергии, транспорт, промышленность, коммерческие, жилые и сельскохозяйственные предприятия. После пика, достигнутого в 2004 году, выбросы в масштабах штата сократились примерно на 25\% (110 млн т CO2е), при этом наблюдался устойчивый рост цен на углерод благодаря рыночным механизмам СА C\&T.

В Калифорнии созданы условия, при которых цена на выбросы углерода стабильно и контролируемо увеличивается с течением времени. Программа ценообразования на углерод в Калифорнии поддерживает законодательно установленный минимальный уровень цен, который ежегодно увеличивается на 5\% плюс инфляция. Кроме того, определенный процент квот зарезервирован для повторного выброса на рынок, если цена достигнет установленного потолка (в 3-4 раза выше текущей торговой цены). Эти меры направлены на предотвращение резких скачков цен, снижение волатильности и ограничение риска снижения цены. С 2017 года все аукционы по продаже квот были распроданы, а клиринговые цены начали подниматься выше ценового минимума, создавая длинный рынок углерода. 
Ожидается, что дельта между минимальной ценой и ценой торгов будет увеличиваться, поскольку спрос, обусловленный промышленным и экономическим ростом, начнет превышать запланированное сокращение предложения. В период с 2021 по 2030 год произойдет обязательное сокращение предельно допустимых выбросов на 4,1\% в годовом исчислении, что приведет к пропорциональному сокращению квот на выбросы углерода.

С 2013 года было получено \$6,4 млрд и \$3,04 млрд только в 2018 году. Большая часть доходов была направлена в Калифорнийский фонд сокращения выбросов парниковых газов, который инвестирует в инфраструктуру и развитие сообществ. По аналогии с EU ETS, капитал от программы ценообразования на углерод в Калифорнии, предназначенный для долгосрочного развития инфраструктуры, снижает политический риск.

С конца 2018 года по конец 2019 года объемы торгов на углеродном рынке Калифорнии составили примерно \$5,5 млрд. Примечательной особенностью рынка Калифорнии было отсутствие понижательной волатильности цен на квоты в течение долгого времени.

Ликвидность резко возросла в течение 2019 года, поскольку на рынок пришли хедж-фонды, что свидетельствует о растущем интересе к углероду как новому классу активов.

\section{RGGI}

Региональная инициатива по парниковым газам (Regional Greenhouse Gas Initiative, RGGI) стала первой обязательной системой торговли эмиссиями (ETS) в США, после того как в 2005 семь северо-восточных штатов заключили соглашение. Система начала работу в 2009 г., и в настоящее время в ней участвуют одиннадцать штатов - Коннектикут, Делавэр, Мэн, Мериленд, Массачусетс, Нью-Гемпшир, НьюЙорк, Род-Айленд, Вермонт, Нью-Джерси и Вирджиния.

RGGI изначально создавался как тестовый рынок для стимулирования федерального правительства к принятию мер по борьбе с изменением климата. Предполагается, что штаты-участники будут все чаще использовать RGGI для достижения климатических целей в отсутствие обязательного федерального углеродного рынка. Это создает возможность расширения региона, более широкого охвата промышленности, установления более строгих целей и увеличения спроса на углеродные квоты, что в конечном итоге будет способствовать росту цен в течение следующих нескольких лет.

Программа охватывает 11\% от общего объема выбросов парниковых газов в регионе, осуществляемых 165 компаниями, работающими на ископаемом топливе и генерирующими электроэнергию. Программа RGGI предусматривает ежегодное снижение предельного уровня выбросов на 2,5\%, что позволило сократить выбросы CO2 на 40\% (32 млн т CO2е) в странах-участницах по сравнению с уровнем 2008 года. 
RGGI использует внутренние механизмы для контроля волатильности цен и ограничения предложения, включая ценовой минимум, резерв сдерживания затрат (CCR) и резерв сдерживания выбросов (ECR).

RGGI установил минимальную цену в \$2,20 в 2018 году с обязательным ежегодным повышением на 2,5\% с учетом инфляции, которая была изменена до $3 \%$ в 2020 году. Механизм CCR выпускает на рынок дополнительные квоты при достижении заранее определенных ценовых потолков (триггерных цен).

Триггерная цена CCR в \$10 была установлена в 2017 году, с запланированным повышением до \$13 в 2021 году и последующим ежегодным повышением на 7\%. В течение десятилетия триггерная цена почти удвоится и составит \$24 в 2030 году, что указывает на ожидаемое постепенное повышение торговой цены за счет ежегодного сокращения предложения квот. В 2021 году RGGI введет ECR - механизм, который автоматически сократит предложение квот, если цены упадут ниже установленного ценового порога. Триггерная цена ECR составит \$6,00 в 2021 году и в дальнейшем будет расти на $7 \%$ в год.

C момента начала действия программы было собрано \$3,08 млрд, которые были возвращены в штаты RGGI для инвестирования в программы для потребителей, такие как: энергоэффективность, возобновляемые источники энергии, прямая помощь в оплате счетов за электроэнергию и другие программы по сокращению выбросов парниковых газов.

Структурные изменения на рынке RGGI, связанные с присоединением новых штатов на северо-востоке, а также сокращение избытка невыплаченных квот способствовали сильному росту цен на квоты RGGI с середины 2017 года. B RGGI пока не наблюдается роста ликвидности вторичного рынка или появления маркетмейкеров и хедж-фондов, как на рынке Калифорнии.

\section{Китайский углеродный рынок}

Китайское министерство экологии и защиты окружающей среды объявило о новых правилах, которым будет подчиняться национальная система торговли выбросами (ETS), которая должна начать работу в июне 2021 г.

Три набора правил, вступившие в силу 17 мая 2021 г., включают в себя «правила управления регистрацией прав на выбросы углерода», «правила управления торговлей выбросами углерода» и «правила управления расчетами прав на выбросы углерода», все три - «для пробного применения».

Правила управления регистрацией прав на выбросы углерода подробно описывают структуру регистрации, ведения счета, обработки информации и управления надзором. Правила управления торговлей правами на выбросы углерода устанавливают минимальный объем торговли квотами на выбросы углерода в размере 1 т эквивалента углекислого газа (CO2e) и минимальное изменение торговой цены в размере 0,01 юаня, которое может быть скорректировано в зависимости от 
ситуации на рынке. Правила управления расчетами прав на выбросы углерода гласят, что агентство по регистрации отвечает за централизованные расчеты, управление средствами и предотвращение рисков расчетов.

Хубейская биржа выбросов (Hubei Emission Exchange) возьмет на себя регистрацию, эксплуатацию и обслуживание счетов прав на выбросы углерода в стране до создания национального реестра прав на выбросы углерода.

Шанхайская биржа окружающей среды и энергии (ЕEЕ) будет отвечать за функционирование системы торговли правами на выбросы углерода до создания национального органа. Шанхайская биржа ЕЕЕ завершила пробное моделирование в марте 2021 г. Шанхайская биржа была выбрана для проведения торговых операций, так как она единственная из семи участников достигла 100-процентного соответствия требованиям в течение семилетнего пробного периода.

C 2011 г. Национальная комиссия по развитию и реформам (NDRC) проводила испытания схем по торговле правами на выбросы углерода в семи провинциях и городах, которые включали Пекин, Шанхай, Тяньцзинь, Чунцин, Гуандун, Шэньчжэнь и Хубэй.

\section{Глобальный углеродный индекс - IHS Global Carbon Index}

Глобальный углеродный индекс IHS Markit сочетает в себе более чем 15-летний опыт индексирования финансовых рынков и глубокие знания в области изменения климата. Индексы IHS Markit охватывают все классы активов, и многие торгуемые продукты привязаны к их индексам. По состоянию на 30 апреля 2019 года под управлением биржевых фондов, ссылающихся на индексы IHS Markit, находится более \$120 млрд. В настоящее время IHS Markit выступает в качестве поставщика аукционных услуг для программы Cap-and-Trade в Калифорнии, Квебеке и Онтарио, которые включает в себя калифорнийские углеродные квоты (California Carbon Allowances, CCA). Кроме того, IHS Markit управляет крупнейшим глобальным добровольным реестром углерода, воды и биоразнообразия, в котором зарегистрировано более 250 миллионов углеродных квот. Глобальный углеродный индекс IHS Markit был разработан совместно с компанией Climate Finance Partners, имеющей более чем 20-летний опыт в области климатического финансирования.

IHS Markit Global Carbon Index предназначен для отслеживания ликвидных, инвестиционно привлекательных сегментов глобального рынка углеродных квот с использованием соответствующих фьючерсных контрактов. Индекс состоит из трех составляющих, которые отличаются значительной ликвидностью и, кроме того, доступны широкому кругу инвесторов через соответствующие фьючерсные контракты. Три составляющих индекса выглядят следующим образом:

- Система торговли эмиссиями EC (EU ETS)

- Углеродные квоты Калифорнии (ССА)

- Региональная инициатива по парниковым газам (RGGI) 
Для того чтобы составляющая индекса могла быть включена в IHS Markit Global Carbon Index, необходимо, чтобы среднемесячный объем торгов по контракту составляюей индекса превышал $\$ 10$ млн в течение шести месяцев до ребалансировки.

Глобальный углеродный индекс IHS Markit ребалансируется 30 ноября определенного года; эта дата совпадает с двухнедельным периодом, когда большинство участников рынка переносят свои фьючерсные контракты в марочные контракты следующего года. Хотя фьючерсы обычно торгуются на бездотационной основе, IHS Markit Global Carbon Index предполагает, что инвестор полностью финансирует фьючерсные позиции, что обеспечивает доходность обеспечения, равную ставке Федеральных фондов овернайт для инвестора. Кроме того, цена IHS Markit Global Carbon Index определяется в долларах США (USD), несмотря на то, что некоторые компоненты, такие как контракты EU ETS, торгуются в других валютах, например, в евро (EUR). Для расчета Глобального углеродного индекса IHS Markit составляющие, которые оцениваются не в долларах США, а в других валютах, конвертируются в доллары США с использованием среднего курса обмена валют.

\section{Внутреннее углеродное ценообразование}

Все большее число организаций используют внутреннее углеродное ценообразование для руководства процессом принятия решений:

- Корпоративное применение внутреннего углеродного ценообразования включает поддержку принятия корпоративных стратегических инвестиционных решений и помощь компаниям в переходе на бизнесмодели с более низким уровнем выбросов углерода.

- Некоторые правительства используют внутреннее углеродное ценообразование в качестве инструмента для процесса закупок, оценки проектов и разработки политики в отношении воздействия изменения климата.

- Финансовые учреждения также начали использовать внутреннее углеродное ценообразование для оценки своего портфеля проектов.

Около двух третей компаний в настоящее время используют внутреннее ценообразование на углерод в качестве инструмента управления рисками.

Текущий охват и ожидаемый рост инициатив по обязательному ценообразованию на углерод способствовали этим изменениям: из компаний, которые публично заявили, что они используют внутреннюю цену на углерод или планируют сделать это в течение следующих двух лет, 83 процента имеют штабквартиры в странах, где обязательное ценообразование на углерод уже действует или планируется к внедрению на национальном или субнациональном уровне. 
Сообщаемые корпоративные цены на углерод, используемые в настоящее время, разнообразны и варьируются от \$0,01/т CO2е до \$909/т CO2е. Некоторые компании используют различные цены на углерод, чтобы учесть разные цены в разных юрисдикциях и/или учесть будущее повышение обязательных цен на углерод. Во всех регионах наблюдается рост числа компаний, раскрывающих информацию о внедренном или планируемом внутреннем углеродном ценообразовании. Широкий диапазон внутренних цен на углерод также указывает на то, что некоторые компании выходят за рамки использования внутреннего ценообразования на углерод в качестве стратегического инструмента управления рисками для оценки потенциального влияния инициатив по установлению цен на углерод на их деятельность. Эти компании также используют его для изучения возможностей экономии затрат и получения прибыли за счет инноваций. Глобальный договор ООН призвал предприятия к 2020 году принять внутреннюю цену на углерод в размере не менее 100 долларов США/тСО2е, что будет необходимо для поддержания выбросов ПГ на уровне $1,5-2^{\circ} \mathrm{C}$.

Инвесторам и предприятиям оказывается поддержка в их реагировании на рекомендации TCFD в рамках инициативы «Коридор углеродного ценообразования». Цель инициативы - определить цены на углерод, необходимые для достижения амбиций Парижского соглашения с точки зрения частного сектора. Для энергетического сектора инициатива показала, что для декарбонизации сектора к 2050 году необходимы цены на углерод в диапазоне \$24-39/т CO2е к 2020 году и \$30100/т СО2е к 2030 году.

Правительства также используют внутреннюю углеродную цену для целей принятия решений, например, для оценки влияния инвестиций в инфраструктуру на климат при экспертизе проектов. Правительства обычно используют три различных подхода к установлению внутренней цены на углерод:

1. Оценка социальной стоимости углерода: социальная стоимость углерода отражает стоимость глобального ущерба, вызванного одной тонной выбросов ПГ. Этот подход подвержен высокому уровню неопределенности, поскольку он опирается на прогнозы состояния экономики, демографических изменений и стоимости мер по адаптации.

2. Оценки предельной стоимости сокращения выбросов: внутренняя цена углерода может быть получена из предельной стоимости сокращения выбросов для достижения национального целевого показателя сокращения выбросов. Оценки этой стоимости основаны на ожиданиях стоимости технологий сокращения выбросов.

3. Текущая и расчетная будущая рыночная стоимость квот на выбросы: внутренние цены на углерод также могут быть основаны на рыночных ценах на квоты на выбросы. Во всех трех случаях затраты увеличиваются со временем по мере роста запасов ПГ. В первом случае затраты увеличиваются, поскольку ожидается, что будущие выбросы принесут больший ущерб на каждую тонну эмитированных ПГ. В двух последних случаях затраты увеличиваются, поскольку предельное сокращение выбросов со временем становится дороже. 
Половина из десяти стран Организации экономического сотрудничества и развития (ОЭСР) с самыми высокими выбросами ПГ сообщили об использовании внутренних цен на углерод. Используемые внутренние цены на углерод варьировались от $\$ 5 /$ т CO2е до более $\$ 400 /$ т CO2е в зависимости от страны, года и сектора, для которого необходимо принять решение.

Финансовые учреждения все чаще используют внутреннее углеродное ценообразование в качестве инструмента для оценки своих инвестиций, включая стоимость углерода в экономический анализ новых проектов. Причины этого лучшее понимание и измерение своего углеродного следа, а также систематическая интеграция негативных внешних факторов выбросов CO2 в оценку проектов в рамках обязательств по поддержке низкоуглеродных решений через свой кредитный портфель.

\section{Как правильно установить цены на углерод}

Инициативы по установлению цен на углерод продолжают совершенствоваться, адаптируясь к новым обстоятельствам и учитывая накопленный опыт. Существующие инициативы по установлению цен на углерод развиваются на основе прошлого опыта, а новые инициативы стараются учесть этот опыт при разработке.

Различные организации опубликовали исследования, призванные помочь правительствам и бизнесу разработать эффективные и рентабельные инструменты для установления цены на социальные издержки выбросов, в том числе:

- Группа Всемирного банка совместно с ОЭСР и при участии МВФ разработала принципы FASTER. Принципами FASTER являются: F справедливость fairness, A - соответствие политики и целей (alignment of policies and objectives), S - стабильность и предсказуемость (stability and predictability), Т - прозрачность (transparency), E - эффективность и рентабельность (efficiency and cost-effectiveness), R - надежность и экологическая целостность (reliability and environmental integrity). Исследование опирается на более чем десятилетний опыт реализации инициатив по установлению цен на углерод во всем мире. Оно указывает на то, чему удалось научиться на сегодняшний день: хорошо продуманная инициатива по установлению цен на углерод является мощным и гибким инструментом, способным сократить выбросы ПГ, а при надлежащей разработке и реализации она может сыграть ключевую роль в стимулировании инноваций и сглаживании перехода к процветающей низкоуглеродной глобальной экономике.

- Партнерство Всемирного банка по готовности к рынку (PMR) совместно с Международным партнерством по углеродным действиям (ICAP) - опубликовали работу «Практика торговли выбросами: 
Руководство по разработке и внедрению» ${ }^{-}$руководство для политиков, в котором собраны лучшие практики и ключевые уроки из более чем десятилетнего практического опыта торговли выбросами во всем мире. Данное Руководство призвано помочь лицам, принимающим решения, политикам-практикам и заинтересованным сторонам достичь этой цели. В нем объясняется обоснование ETS и излагается 10-этапный процесс разработки ETS - каждый этап включает ряд решений или действий, которые определяют основные характеристики политики.

- Партнерство Всемирного банка по готовности к рынку (PMR) опубликовало «Руководство по углеродным налогам: справочник для разработчиков политики». ${ }^{6}$ Данное руководство преследует две основные цели. Во-первых, оно служит практическим инструментом, помогающим политикам определить, является ли углеродный налог подходящим инструментом для достижения целей национальной политики. Во-вторых, это ресурс для поддержки разработки и внедрения налога, который наилучшим образом соответствует конкретным потребностям, обстоятельствам и целям национальной политики. Руководство содержит как концептуальный анализ, так и важные практические уроки, извлеченные из внедрения углеродных налогов по всему миру.

- Партнерство Всемирного банка по готовности к рынку (PMR) опубликовало "Руководство по бенчмаркингу парниковых газов для инструментов климатической политики".7 Руководство предназначено для предоставления политикам структурированного руководства по разработке контрольных показателей и опирается на более чем десятилетний мировой опыт разработки контрольных показателей, охватывая практику в 16 юрисдикциях, которые уже используют или находятся в процессе разработки подхода к контрольным показателям.

- Европейская комиссия опубликовала справочник EU ETS8, в котором содержится подробная информация о Системе торговли выбросами ЕС (EU ETS), включая информацию о том, как была разработана система и как она функционирует.

- Глобальный договор ООН и Институт мировых ресурсов совместно с партнерством «Забота о климате» (Caring for Climate partners) опубликовали «Руководство для руководителей по лидерству в ценообразовании на углерод».9 В руководстве описывается значение различных внутренних подходов к ценообразованию на углерод и приводятся примеры из практики компаний, иллюстрирующие, как предприятия применяют их на практике.

\footnotetext{
${ }^{5}$ https://openknowledge.worldbank.org/handle/10986/23874

${ }^{6}$ https://openknowledge.worldbank.org/handle/10986/26300

7 https://elibrary.worldbank.org/doi/abs/10.1596/26848

8 https://ec.europa.eu/clima/sites/clima/files/docs/ets_handbook_en.pdf

9 https://www.unglobalcompact.org/library/3711
} 
- Европейский банк реконструкции и развития (ЕБРР) и Грэнтемский исследовательский институт по вопросам изменения климата и окружающей среды (Grantham Research Institute on Climate Change and the Environment) опубликовали специальный доклад «Изменение климата: переход к низкоуглеродной экономике».10 В отчете представлены политические меры, необходимые для сокращения выбросов углерода в Центральной и Восточной Европе и Центральной Азии, включая ценообразование на углерод. В докладе освещаются проблемы и возможности ценообразования на углерод в контексте участия стран с переходной экономикой в глобальных усилиях по смягчению последствий изменения климата.

- Азиатский банк развития опубликовал доклад «Схемы торговли выбросами и их увязка: вызовы и возможности для Азии и АТР». ${ }^{11}$ В докладе обобщены некоторые из наиболее значимых на сегодняшний день примеров взаимной увязки ETS и обсуждаются некоторые решения для проблем, с которыми пришлось столкнуться. В нем также рассматриваются возможности для будущих связанных углеродных рынков в Азиатско-Тихоокеанском регионе.

- Ecofys, The Generation Foundation и CDP разработали руководство по лучшей практике внутреннего углеродного ценообразования в компаниях. ${ }^{12}$ Используя новую четырехмерную схему, руководство объясняет, как можно установить передовой подход к внутреннему углеродному ценообразованию для оптимизации декарбонизации в цепочке создания стоимости компании.

- Практически все сценарии достижения целей Парижского соглашения включают часть эмиссий, которые предполагается удалить из атмосферы. Это две стороны процесса декарбонизации - сокращение выбросов и удаление имеющейся в атмосфере углекислоты. Этот подход также подтвержден в сценарии достижения чистых нулевых эмиссий к 2050 году, представленному МЭА ${ }^{13}$. Сценарий IEA NZE предполагает значительно меньший объем накопленных эмиссий, который надо удалить из атмосферы, по сравнению со сценариями IPCC - 1,9 млрд т против 3,5-16,1 млрд т СО2 к 2050 г. соответственно. Но в любом случае, потребуется финансирование нейтрализации больших объемов углекислого газа.

- Международное партнерство по действиям в области углеродного регулирования (The International Carbon Action Partnership, ICAP)

\footnotetext{
${ }^{10}$ https://www.ebrd.com/news/publications/special-reports/special-report-on-climate-change-the-lowcarbon-transition.html

${ }^{11} \mathrm{https}: / / \mathrm{www}$. adb.org/publications/emissions-trading-schemes-and-their-linking

12 https://b8f65cb373b1b7b15feb-

c70d8ead6ced550b4d987d7c03fcdd1d.ssl.cf3.rackcdn.com/cms/reports/documents/000/002/740/original/cpu-2017how-to-guide-to-internal-carbon-pricing.pdf?1521554897

${ }^{13}$ https://www.iea.org/reports/net-zero-by-

2050?utm_content=buffer2ff67\&utm_medium=social\&utm_source=twitter.com\&utm_campaign=buffer
} 
выпустило доклад о роли ценообразования на углерод и в частности о системах торговли эмиссиями (ETS). ${ }^{14}$

\section{Практика ценообразования}

В 2019 году цены на мировом углеродном рынке варьировались от \$1 до \$30 за тонну углерода (CO2e), при этом половина торговли осуществлялась на уровне ниже \$10/т CO2е. Рыночные цены определяются динамикой спроса и предложения, механизмами внутренней политики углеродного рынка, которые поддерживают цену и ограничивают предложение, а также различными макроэкономическими и геополитическими силами, такими как структура энергобаланса и климатические риски. С момента принятия Парижского соглашения наблюдается постепенное повышение средней цены на углерод.

Однако существует расхождение между текущими рыночными ценами и политикой, лежащей в основе таких рынков, что свидетельствует о необходимости ценообразования, которое лучше отражает истинную стоимость выбросов углерода. Комиссия высокого уровня по ценам на углерод (коалиция правительственных организаций и частного сектора, спонсируемая ООН и Всемирным банком) ${ }^{15}$ указывает, что для выполнения целей Парижского соглашения цены на углерод должны быть в диапазоне \$40-80/т CO2 к 2020 году и \$50-100/т CO2 к 2030 году.

Предполагается, что эти цены установятся при реализации достаточно амбициозной климатической политики. Со временем цены на разных сегментах рынка должны сблизиться, что является целью единой цены на углерод в рамках Глобального углеродного индекса.

Подавляющее большинство торговых операций на первичном рынке базовых активов, связанных с квотами на выбросы углекислого газа, осуществляют предприятия-эмитенты, поскольку нормативные ограничения и лимиты на владение активами создают значительные препятствия для владения ими. Поэтому торговая деятельность на вторичном рынке происходит на фьючерсных рынках, а не на самих рынках базовых углеродных квот.

Фьючерсный рынок углеродных квот обеспечивает ликвидность для держателей углеродных квот и позволяет участникам рынка либо хеджировать, либо спекулировать на возможной волатильности цен в будущем. Участниками фьючерсного рынка являются коммунальные предприятия, промышленные компании, институциональные инвесторы, хедж-фонды и правительства. Некоторые из этих участников стремятся к физической поставке углеродных квот, в то время как другие нацелены на финансовые расчеты.

Фьючерсы, по определению, получают свою стоимость от базового инструмента, против которого они выписаны, и, следовательно, фьючерсы на

\footnotetext{
${ }^{14} \mathrm{https}$ ://icapcarbonaction.com/en/?option=com_attach\&task=download\&id=723

15 https://www.carbonpricingleadership.org/highlevel-commission-on-carbon-pricing-and-competitiveness
} 
углеродные квоты и их физические эквиваленты углеродных квот сильно коррелируют друг с другом. Наличие арбитражных возможностей на рынке обеспечивает сохранение этой корреляции, учитывая способность участников рынка довольно легко покупать или продавать эти базовые квоты или фьючерсы. Таким образом, структурные зависимости в ценообразовании двух ценных бумаг приводят к тому, что цены движутся синхронно.

\section{Биржевая углеродная инициатива}

Идея торговли углеродными квотами или единицами компенсаций на глобальном уровне набирает силу. Различные региональные схемы ограничения и торговли углеродными единицами рынки уже развивают углеродный рынок, но крупнейшие мировые биржи только начинают прощупывать почву и пытаются организовать первые торговые схемы и внедрить первые инструменты. Чикагская товарная биржа объявила, что предлагает решение для определения мировых котировок углеродных единиц. 16

Растущая конкуренция должна позволить углеродным квотам найти равновесную цену. Новый фьючерсный контракт включает в себя критерии, которые компании в различных отраслях могут использовать для оценки квот на эмиссии.

Переход на чистые источники энергии в 2020 году позволил многим компаниям сократить эмиссии парниковых газов. Уже 120 стран, 23 региона, 454 города, 1397 компании, 74 инвестиционных фонда и 569 университетов по всему миру приняли на себя обязательства достичь углеродной нейтральности к 2050 году. Многие из этих потенциальных участников углеродного рынка могут быть заинтересованы в рыночном механизме, помогающем осуществлять индивидуальные стратегии.

Схемы торговли эмиссиями создаются для предоставления эффективного механизма для стран, компаний и даже отдельных людей, желающих сократить свой углеродный след. В теории все просто: растущая конкуренция и доступность рынка должны привести углеродные цены к равновесию.

Тем не менее, уникальность и региональная природа торговли эмиссиями и углеродными квотами препятствует гармонизации программ и получению стандартизированной цены. Поэтому это сложная задача - сокращать климатические риски без образования глобального бенчмарка.

Рабочая группа по масштабированию добровольных углеродных рынков (Тhe Taskforce on Scaling Voluntary Carbon Markets, TSVCM), проект, образованный при поддержке Института международных финансов (IIF), куда входят крупнейшие финансовые организации (450 компаний из более чем 70 стран), в работе которой участвует также Чикагская товарная группа (CME Group), инициировала создание

${ }^{16}$ https://www.cmegroup.com/openmarkets/commodities/finding-a-solution-for-global-carbon-offsets- 
«крупного, прозрачного, верифицируемого и устойчивого добровольного углеродного рынка, который должен стать критически важным элементом достижения целей углеродной нейтральности». Но для достижения этой цели рынок добровольных сокращений эмиссий должен вырасти в 15 раз. И среди ключевых рекомендаций по такому масштабированию рынка обозначена необходимость создания фьючерсного рынка.

В августе 2021 г. рабочая группа TSVCM объявила о переходе к реализации дорожной карты, опубликованной месяцем ранее. К концу 2021 года планируется сформировать независимый орган управления рынком, который начнёт работать над единой правовой базой и основными углеродными принципами (ССР), регулирующими торговлю такими углеродными единицами.

CME Group и Xpansiv markets CBL, лидер на спотовых рынках энергоресурсов, совместно разработали Глобальный фьючерсный контракт квот на эмиссии (Global Emissions Offset, GEO). Фьючерсный контракт GEO установит основания для выработки критериев определения квот и типов проектов, которые будут соответствовать биржевому обороту.

\section{Список источников:}

1. https://www.climatepolicyinitiative.org/the-topics/climate-finance-landscapes/

2. https://unfccc.int/ru/peregovornyy-process-i-vstrechi/parizhskoe-soglashenie/nationally-determinedcontributions-ndcs/opredelyaemye-na-nacionalnom-urovne-vklady

3. https://unfccc.int/resource/docs/2015/cop21/rus/10r.pdf

4. https://openknowledge.worldbank.org/handle/10986/23874

5. https://openknowledge.worldbank.org/handle/10986/26300

6. https://elibrary.worldbank.org/doi/abs/10.1596/26848

7. https://ec.europa.eu/clima/sites/clima/files/docs/ets_handbook_en.pdf

8. https://www.unglobalcompact.org/library/3711

9. https://www.ebrd.com/news/publications/special-reports/special-report-on-climate-change-the-lowcarbon-transition.html

10. https://www.adb.org/publications/emissions-trading-schemes-and-their-linking

11. https://b8f65cb373b1b7b15febc70d8ead6ced550b4d987d7c03fcdd1d.ssl.cf3.rackcdn.com/cms/reports/documents/000/002/740/origin al/cpu-2017-how-to-guide-to-internal-carbon-pricing.pdf?1521554897

12. https://www.iea.org/reports/net-zero-by2050?utm_content=buffer $2 \mathrm{ff} 67 \& u t m \_$medium $=$social\&utm_source=twitter.com\&utm_campaign=buff er

13. https://icapcarbonaction.com/en/?option=com_attach\&task=download\&id=723

14. https://www.carbonpricingleadership.org/highlevel-commission-on-carbon-pricing-andcompetitiveness

15. https://www.cmegroup.com/openmarkets/commodities/finding-a-solution-for-global-carbon-offsetspricing.html 